\title{
Boiling Points of Aqueous Solutions of Dextrose Within the Pressure Range of 200 to 1,500 Millimeters
}

\author{
By John L. Torgesen, ${ }^{1}$ Vincent E. Bower, and Edgar R. Smith
}

\begin{abstract}
By using twin ebulliometers of the Swietoslawski type, with water as the reference standard, data were obtained on the vapor-pressure-temperature relationship for aqueous solutions of dextrose. The pressures ranged from 200 to 1,500 millimeters and the concentrations of the solutions from 10 to 60 percent of dextrose by weight. The vapor-pressuretemperature relationship is expressed by equations of the form
\end{abstract}

$$
\log _{10} p=A-\frac{B}{C+t}
$$

in which $p$ is the vapor pressure in standard millimeters of mercury exerted by a solution of a given concentration at the temperature, $t$, in degrees Celsius. $A, B$, and $C$ are constants. The boiling-point elevations of aqueous dextrose solutions at a given pressure are expressed by equations of the form

$$
\log _{10} \Delta t=\alpha+\beta c+\gamma c^{2}+\delta c^{3},
$$

in which $\Delta t$ represents the boiling-point elevation in degrees Celsius at a given pressure, $c$ is the concentration in weight percentage of dextrose, and $\alpha, \beta, \gamma$, and $\delta$ are constants.

\section{Introduction}

The boiling points and boiling-point elevations of aqueous solutions of dextrose within the pressure range of 200 to $1,500 \mathrm{~mm}$ and the concentration range of 10 to 60 percent of dextrose by weight are reported in this paper. This work is part of a program sponsored by the Corn Industries Research Foundation to obtain physical data for materials of importance in the manufacture of various corn products.

The method used was a comparative dynamic one for measuring successively, with the same thermometer, the boiling point of a given solution and that of water in twin ebulliometers connected to a manostat. A series of corresponding boiling points of the solutions and of water at various pressures was thus obtained. The values of $t_{s}$, the boiling point of a solution of dextrose, and $t_{w}$, the corresponding boiling point of water at the various pressures were related by equations of the form

$$
t_{s}=a+b t_{w}+c t_{w}^{2},
$$

in which the constants $a, b$, and $c$ for each concentration of dextrose were evaluated by the method of least squares. The values of $t_{w}$ and the corresponding pressures taken as reference standards were selected from the compilation of Osborne, Stimson and Ginnings [1] ${ }^{2}$ and have previously been tabulated in convenient form [2].

No equation was found to relate the boiling points of the solutions to their concentrations, at a given pressure, with the precision of the experimental data. For this reason the boiling points of solutions

${ }_{1}^{1}$ Research Associate at the National Bureau of Standards, representing the Corn Industries Research Foundation.

2 Figures in brackets indicate the literature references at the end of this paper. of even values of concentration were obtained graphically by plotting $\Delta t$, the boiling point elevation given by the difference between $t_{s}$ and $t_{w}$, with respect to the concentration (or $\Delta t /$ concentration versus concentration). From the resultant series of curves, one for each of the standard reference pressures, the values of $\Delta t$ for even concentrations of dextrose were obtained, and the boiling points of the solutions were evaluated by adding the corresponding boiling point of water. These boiling points of the solutions were tabulated with their corresponding pressures and the constants $A, B$, and $C$ in the Antoine equation [3]

$$
\log p=A-\frac{B}{C+t},
$$

were evaluated to obtain the relationship between vapor pressure and temperature for each of the several even concentrations. (The symbol "log" is used in this paper to denote the logarithm to the base 10.) Equation 2 is explicit in temperature when written in the form $t=B /(A-\log p)-C$. Also

$$
\frac{d p}{d t}=\frac{p(A-\log p)^{2}}{B \log e} .
$$

The best equation that was found to represent the relationship between the measured boiling point elevations and the concentrations is of the form [4]

$$
\log \Delta t=\alpha+\beta c+\gamma c^{2}+\delta c^{3},
$$

in which the constants $\alpha, \beta, \gamma$, and $\delta$ were evaluated by the method of least squares. But a comparison of the computed with the observed values of the boiling point elevation at a given pressure shows deviations that are several times larger than the precision of the original data. 


\section{Apparatus and Materials}

Except for minor changes, the apparatus was the same as described in a previous paper [2]. Two simple barometric ebulliometers, of the type developed by Swietoslawski [5], were sealed to a manostat. In the case of the solution ebulliometer, a flask containing water was interposed to inhibit the loss of water vapor from the solution to the manostat. Pressures below atmospheric were obtained with a mechanical pump, and those above were obtained by the addition of nitrogen from a cylinder.

The solutions of dextrose were prepared from NBS Standard Sample dextrose previously dried in a vacuum oven at $60^{\circ}$ to $70^{\circ} \mathrm{C}$ for 6 hours and weighed into known weights of water. All concentrations, expressed in weight percentage on a vacuum basis, are corrected for the vapor and liquid hold-up that prevailed in the ebulliometer during the boiling procedure. Crystalline $\alpha$-dextrose undergoes mutarotation in aqueous solution to form an equilibrium mixture of $\alpha$ - and $\beta$-dextrose [6]. The rate of the conversion is dependent on the temperature and $\mathrm{pH}$ of the solution, and the equilibrium amounts of $\alpha$ - and $\beta$-dextrose present depend on the temperature and concentration of the solution. Hence the solutions studied contained a mixture of $\alpha$ - and $\beta$ dextrose. However, since both forms possess identical molecular weights, no effect on the boiling point or the vapor pressure of a solution is to be expected as a result of different ratios of the two isomeric forms at different temperatures and concentrations.

The solution ebulliometer was charged with a known weight and volume of solution, the water ebulliometer with the proper volume of distilled water and the filling tubes sealed off. Boiling temperatures were measured at as near the same boiling rate as could conveniently be achieved, the rate being controlled to return approximately 20 drops of condensate per minute to the boiler as observed in the drop-counter placed in the return tube. This boiling rate approximates the midpoint of the flat constant-temperature portion of the curve obtained by plotting boiling temperature with respect to boiling rate [5] and was determined by initial experiments. The comparative measurements of temperature were made with a platinum resistance thermometer (coiled filament type) and a Mueller thermometer bridge by the method described in another paper from this laboratory [7]. The temperatures were measured to $0.001 \mathrm{deg} \mathrm{C}$, with an average reproducibility of 0.002 to $0.003 \mathrm{deg} \mathrm{C}$ and an estimated accuracy of $0.005 \mathrm{deg} \mathrm{C}$ on the International Temperature Scale. It was not necessary to hold the bridge at constant temperature, as the temperature corrections to the resistances were practically identical for the temperatures of the reference and measured substances in these comparative measurements.

The ratios of the boiling points of the solutions to those of water at normal atmospheric pressure taken at the beginning and end of a series of measurements did not differ by more than 0.008 percent in the extreme case of the most concentrated solution. The average difference for the several concentrations studied was 0.003 percent. Refractive index measurements on the original and boiled solutions were practically identical. It is believed that no significant change in concentration occurred during the boiling procedure, although the solutions of higher concentration assumed a slight yellowish tint, particularly after koiling at the higher pressures. Specific rotations were not measured.

\section{Experimental Results}

The correction for the water vapor and liquid hold-up in the ebulliometer, to be applied to the concentrations of the solutions as originally prepared, was determined experimentally by using solutions of sodium chloride. For this purpose, a stopcock was sealed temporarily at the bottom of the solution ebulliometer for rapid withdrawal of samples while boiling. Solutions of sodium chloride of different known concentrations were placed in the solution ebulliometer and boiled in the usual fashion at normal atmospheric pressure. When boiling equilibrium had become established, as evidenced by steady boiling temperatures, a $25-\mathrm{ml}$ sample was quickly withdrawn into a flask that was surrounded by ice water to minimize the loss of water vapor.

TABLE 1. Determination of ebulliometer hold-up

\begin{tabular}{|c|c|c|c|c|}
\hline Charge & $\begin{array}{c}\text { Original } \\
\text { concentra- } \\
\text { tion of } \\
\mathrm{NaCl}\end{array}$ & $\begin{array}{c}\text { Boiling } \\
\text { rate }\end{array}$ & $\begin{array}{l}\text { Boiling } \\
\text { concentra- } \\
\text { tion of } \\
\mathrm{NaCl}\end{array}$ & Hold-up \\
\hline $\begin{array}{c}g \\
65.086 \\
65.110 \\
65.135 \\
70.008 \\
69.963 \\
70.087\end{array}$ & $\begin{array}{l}\text { Percent } \\
11.760 \\
11.760 \\
11.760 \\
22.195 \\
22.195 \\
22.195\end{array}$ & $\begin{array}{c}\text { Drops/min } \\
12 \\
20 \\
30 \\
12 \\
20 \\
30\end{array}$ & $\begin{array}{l}\text { Percent } \\
11.873 \\
11.891 \\
11.898 \\
22.391 \\
22.413 \\
22.440\end{array}$ & $\begin{array}{c}g \\
0.62 \\
.71 \\
.75 \\
.61 \\
.68 \\
.76\end{array}$ \\
\hline
\end{tabular}

The samples were analyzed for sodium chloride by evaporation to dryness in platinum dishes on a steam bath, followed by heating to incipient fusion and weighing the sodium-chloride residue. The difference in concentration between the original and the boiling solution, together with the knowledge of the amount of original charge in the ebulliometer, provided data for the calculation of the hold-up of liquid and vapor while boiling was taking place at normal atmospheric pressure. It was assumed that the liquid hold-up remains essentially constant at all pressures involved. The vapor hold-up, which depends on the pressure and temperature, could be closely estimated from the knowledge of the free volume of the ebulliometer. Since this method of determining the hold-up may be of interest, the results are given in table 1 . From these results, the amount of liquid and vapor hold-up at 20 drops a minute, which was the boiling rate employed in this work, was taken as $0.68 \mathrm{~g}$, of which $0.61 \mathrm{~g}$ is attributed to liquid hold-up on the walls of the apparatus, and $0.07 \mathrm{~g}$ is a calculated value for the 
TABLE 2. Corresponding boiling points of dextrose solutions and water

\begin{tabular}{|c|c|c|c|c|c|c|c|c|c|c|c|c|c|}
\hline $\begin{array}{c}\text { 10.34- } \\
\text { percent } \\
\text { solution }\end{array}$ & Water & $\begin{array}{l}21.26- \\
\text { percent } \\
\text { solution }\end{array}$ & Water & $\begin{array}{c}32.50- \\
\text { percent } \\
\text { solution }\end{array}$ & Water & $\begin{array}{l}\text { 40.31- } \\
\text { percent } \\
\text { solution }\end{array}$ & Water & $\begin{array}{c}50.54- \\
\text { percent } \\
\text { solution }\end{array}$ & Water & $\begin{array}{l}59.69- \\
\text { percent } \\
\text { solution }\end{array}$ & Water & $\begin{array}{c}63.23- \\
\text { percent } \\
\text { solution }\end{array}$ & Water \\
\hline${ }^{\circ} \mathrm{C}$ & ${ }^{\circ} \mathrm{C}$ & ${ }^{\circ} \mathrm{C}$ & ${ }^{\circ} \mathrm{C}$ & ${ }^{\circ} \mathrm{C}$ & ${ }^{\circ} \mathrm{C}$ & ${ }^{\circ} \mathrm{C}$ & ${ }^{\circ} \mathrm{C}$ & ${ }^{\circ} \mathrm{C}$ & ${ }^{\circ} \mathrm{C}$ & ${ }^{\circ} \mathrm{C}$ & ${ }^{\circ} \mathrm{C}$ & ${ }^{\circ} \mathrm{C}$ & ${ }^{\circ} \mathrm{C}$ \\
\hline 100.054 & 99.724 & 100.567 & 99. 788 & 101. 286 & 99. 869 & 101. 686 & 99.686 & 103. 237 & 100. 063 & 104.806 & 100. 059 & 105.386 & 99.867 \\
\hline 100.063 & 99.732 & 100.563 & 99. 783 & 101. 293 & 99.876 & 101.685 & 99. 684 & 103. 246 & 100.072 & 104.813 & 100.066 & 101.163 & 95. 745 \\
\hline 94.182 & 93.863 & 94.267 & 93.514 & 95. 533 & 94.163 & 95. 258 & 93.330 & 99. 271 & 96.170 & 98.302 & 93.711 & 96.579 & 91. 272 \\
\hline 94.200 & 93.881 & 94.273 & 93.520 & 87.802 & 86.490 & 87.725 & 85.879 & 103. 323 & 100.140 & 90.880 & 86.462 & 91.387 & 86. 222 \\
\hline 86.414 & 86.109 & 86.927 & 86. 207 & 81.624 & 80.358 & 80.303 & 78. 523 & 99. 134 & 96.044 & 80.696 & 76.489 & 84.844 & 79. 809 \\
\hline 86.433 & 86.128 & 86.940 & 86. 220 & 92.864 & 91.513 & 93.033 & 91.122 & 94.684 & 91.673 & 69.077 & 65.092 & 76.686 & 71.771 \\
\hline 75. 946 & 75. 652 & 76.675 & 75. 992 & 101. 389 & 99. 965 & 101.483 & 99.472 & 89.448 & 86.522 & 90.914 & 86.488 & $\begin{array}{r}10.05 .293 \\
105\end{array}$ & 99. 742 \\
\hline 75.977 & 75.684 & 76.704 & 76.021 & 101. 653 & 100. 229 & 101. 701 & 99. 686 & 82.844 & 80.011 & 104. 634 & 99.882 & 110.639 & 104. 931 \\
\hline 100.261 & 99.929 & 64.876 & 64. 232 & 101.653 & 100. 233 & 101.698 & 99. 688 & 75.432 & 72. 705 & 111. 295 & 106.362 & 115.148 & 109. 315 \\
\hline 100.261 & 99.928 & 64.940 & 64. 292 & 106.877 & 105.417 & 106.970 & 104.898 & 103.161 & 99.985 & 117. 229 & 112.147 & 119.269 & 113.303 \\
\hline 105.559 & 105.218 & 78.142 & 77. 455 & 111.307 & 109. 798 & 111.431 & 109.306 & 103.162 & 99. 990 & 122. 262 & 117.038 & 122.863 & 116. 788 \\
\hline 105.562 & 105.220 & 87. 363 & 86.638 & 115. 220 & 113. 683 & 115. 416 & 113. 248 & 108. 270 & 105. 011 & 125.670 & 120.369 & 126. 482 & 120.304 \\
\hline 109.860 & 109.507 & 94.550 & 93.793 & 118. 782 & 117. 212 & 119.115 & 116. 895 & 112. 778 & 109.442 & 116.143 & 111. 123 & 105. 324 & 99.795 \\
\hline 109.862 & 109.511 & 100.616 & 99.832 & 122.419 & 120.805 & 122. 526 & 120. 264 & 116. 880 & 113.457 & 104.542 & 99.828 & & \\
\hline 113.867 & 113.508 & 100.791 & 100.007 & 101.522 & 100.098 & 116. 730 & 114.542 & 120.461 & 116. 972 & & & & \\
\hline 113.873 & 113.512 & 105.994 & 105. 186 & & & 110.091 & 107. 987 & 123.864 & 120. 324 & & & & \\
\hline 117. 356 & 116.988 & 110.293 & 109. 463 & & & 101. 731 & 99. 722 & 103. 191 & 100.031 & & & & \\
\hline 117.364 & 116. 994 & 114.495 & 113.649 & & & & & & & & & & \\
\hline 120.838 & 120.461 & 117.897 & 117.030 & & & & & & & & & & \\
\hline 120.844 & 120.462 & 121.007 & 120.118 & & & & & & & & & & \\
\hline 118. 216 & 117.843 & & & & & & & & & & & & \\
\hline 118. 224 & 117.850 & 117.891 & 117.023 & & & & & & & & & & \\
\hline 114. 205 & 113.843 & 114.405 & 113.556 & & & & & & & & & & \\
\hline 114. 214 & 113.851 & 110.298 & 109. 469 & & & & & & & & & & \\
\hline 110.450 & 110.095 & 105.852 & 105.044 & & & & & & & & & & \\
\hline 110.458 & 110.104 & 100.689 & 99. 907 & & & & & & & & & & \\
\hline 106. 190 & 105.844 & & & & & & & & & & & & \\
\hline 106. 200 & 105.855 & & & & & & & & & & & & \\
\hline $\begin{array}{l}100.266 \\
100.230\end{array}$ & $\begin{array}{l}99.934 \\
99.896\end{array}$ & & & & & & & & & & & & \\
\hline 100.235 & 99.902 & & & & & & & & & & & & \\
\hline 94. 021 & 93.699 & & & & & & & & & & & & \\
\hline 94. 034 & 93.712 & & & & & & & & & & & & \\
\hline $\begin{array}{l}\text { 86. } 212 \\
\text { 86. } 228\end{array}$ & $\begin{array}{l}85.905 \\
85.922\end{array}$ & & & & & & & & & & & & \\
\hline 76. 098 & 75. 799 & & & & & & & & & & & & \\
\hline 76. 124 & $\begin{array}{l}75.825 \\
62.297\end{array}$ & & & & & & & & & & & & \\
\hline 62.641 & $\begin{array}{l}\text { 62. } 297 \\
62.344\end{array}$ & & & & & & & & & & & & \\
\hline 77. 031 & 76.732 & & & & & & & & & & & & \\
\hline 86. 288 & 85. 982 & & & & & & & & & & & & \\
\hline 94. 084 & 93.763 & & & & & & & & & & & & \\
\hline 100.080 & 99,747 & & & & & & & & & & & & \\
\hline
\end{tabular}

vapor hold-up at $760-\mathrm{mm}$ pressure and the boiling temperature. At 200 - and $1,500-\mathrm{mm}$ pressure the calculated vapor hold-up is 0.02 and $0.12 \mathrm{~g}$, respectively, giving a total hold-up at these extreme pressures of 0.63 and $0.71 \mathrm{~g}$, respectively, assuming that the liquid hold-up remains constant over this pressure range.

The comparative boiling points of dextrose solutions of several concentrations and water, in the order as actually measured, are given in table 2 . The concentrations listed are those prevailing during the boiling procedure at $760-\mathrm{mm}$ pressure. The change in concentration accompanying the change in vapor hold-up with variation of the pressure is small but can be significant, particularly for the more concentrated solutions. For example, a 10percent solution changes in concentration by -0.01 percent at $200 \mathrm{~mm}$ and by +0.01 percent of dextrose at $1,500 \mathrm{~mm}$. A 60 -percent solution changes by -0.04 and +0.04 percent at these extreme pressures.

By means of eq 1 the boiling points of the dextrose solutions were expressed as functions of the boiling points of water over the pressure range involved. The constants $a, b$, and $c$ for each of the solutions are given in table 3 . The average and maximum devia- tions of the experimental points from those calculated by eq 1 with the appropriate constants are given in the last two columns. The average deviations increase from $\pm 0.002 \mathrm{deg} \mathrm{C}$ in the case of the more dilute solutions to $\pm 0.013 \mathrm{deg} \mathrm{C}$ for the most concentrated solution. An explanation for the increasing experimental deviations at higher concentrations of dextrose is that the boiling equilibrium in the latter cases is established with less certainty. The pumping action in the ebulliometers is probably less efficient because of the increased viscosity of the solutions and, also, the concentration of the solution in the boiler may vary due to incomplete mixing of the condensate with the highly concentrated solution.

The boiling temperatures of the solutions at the standard reference pressures were calculated by means of eq 1 with the constants from table 3 . The difference between the boiling temperatures of solution and water at a given pressure represents the boiling-point elevation, $\Delta t$, at that pressure. For each reference pressure, $\Delta t$ was plotted with respect to the concentration on a scale that permitted the plotting and reading of temperatures to $\pm 0.005 \mathrm{deg} C$ and of concentrations to \pm 0.01 percent of dextrose. 
Values of $\Delta t$ at even concentrations were read from the curves and added to the corresponding boiling points of water to obtain the boiling temperatures of the solutions listed in table 4 at the reference pressures. A separate set of the constants $A, B$, and $C$ in eq 2 was evaluated to fit the data for each solution given in table 4 . Values of the constant $C$ were determined by the method of averages, followed by an evaluation of constants $A$ and $B$ by the method of least squares. The values of the constants are given in table 5. The over-all average deviation of the vapor-pressure-temperature relationships ex-

TABLE 3. Boiling points of dextrose solutions in terms of the boiling points of water

\begin{tabular}{|c|c|c|c|c|c|}
\hline \multicolumn{6}{|c|}{$t_{s}=a+b t_{w}+c t_{w^{2}}$} \\
\hline $\begin{array}{l}\text { Concen- } \\
\text { tration of } \\
\text { dextrose }\end{array}$ & $a$ & $b$ & $c$ & $\begin{array}{c}\text { Average } \\
\text { deviation }\end{array}$ & $\begin{array}{l}\text { Maxi- } \\
\text { mum de- } \\
\text { viation }\end{array}$ \\
\hline $\begin{array}{r}\text { Percent } \\
10.34 \\
21.26 \\
32.50 \\
40.31 \\
50.54 \\
59.69 \\
63.23\end{array}$ & $\begin{array}{r}0.3376 \\
.5516 \\
.9815 \\
1.2027 \\
1.9000 \\
3.2872 \\
4.7004\end{array}$ & $\begin{array}{r}0.997929 \\
.999929 \\
1.000342 \\
1.004451 \\
1.007563 \\
1.003618 \\
.988355\end{array}$ & $\begin{array}{l}0.2011 \times 10^{-4} \\
.2377 \\
.4030 \\
.3626 \\
.5115 \\
1.0354 \\
2.0042\end{array}$ & $\begin{array}{c}{ }^{\circ} C \\
\pm 0.002 \\
\pm .002 \\
\pm .003 \\
\pm .004 \\
\pm .007 \\
\pm .009 \\
\pm .013\end{array}$ & $\begin{array}{c}{ }^{\circ C} \\
\pm 0.003 \\
\pm .004 \\
\pm .003 \\
\pm .007 \\
\pm .012 \\
\pm .026 \\
\pm .023\end{array}$ \\
\hline
\end{tabular}

pressed by eq 2 is $\pm 0.04 \mathrm{~mm}$. The larger maximum deviations shown in the last column of table 5 were at the highest pressure, $1489.14 \mathrm{~mm}$, in every case. Values of the temperature and rates of change of pressure with temperature at even values of the pressure are given in table 6 .

The relationship between boiling point elevation and concentration was obtained by using the data in table 3 to calculate the boiling points of the solutions and boiling point elevations at the reference pressures. From the tabulations of $\Delta t$ and concentration at a given pressure the constants $\alpha, \beta, \gamma$, and $\delta$ in eq 4
TABLE 4. Boiling points of dextrose solutions at standard reference pressures

\begin{tabular}{|c|c|c|c|c|c|c|c|}
\hline \multirow{2}{*}{ Pressure } & \multirow{2}{*}{$\begin{array}{c}\text { Boil- } \\
\text { ing } \\
\text { point } \\
\text { of } \\
\text { water }\end{array}$} & \multicolumn{6}{|c|}{ Boiling point of solutions } \\
\hline & & $10 \%$ & $20 \%$ & $30 \%$ & $40 \%$ & $50 \%$ & $60 \%$ \\
\hline$m m \mathrm{Hg}$ & ${ }^{\circ} \mathrm{C}$ & ${ }^{\circ} \mathrm{C}$ & ${ }^{\circ} \mathrm{C}$ & ${ }^{\circ} \mathrm{C}$ & ${ }^{\circ} \mathrm{C}$ & ${ }^{\circ} \mathrm{C}$ & ${ }^{\circ} \mathrm{C}$ \\
\hline 187.57 & 65 & 65.277 & 65.600 & 66.047 & 66.624 & 67.555 & 69.045 \\
\hline 233.72 & 70 & 70.280 & 70.615 & 71.073 & 71.670 & 72.625 & 74.137 \\
\hline 289.13 & 75 & 75. 284 & 75. 631 & 76. 101 & 76.718 & 77.697 & 79.235 \\
\hline 355.22 & 80 & 80.289 & 80.648 & 81.130 & 81.767 & 82.772 & 84. 338 \\
\hline 433.56 & 85 & 85. 295 & 85. 666 & 86.161 & 86.818 & 87.849 & 89.446 \\
\hline 525.86 & 90 & 90.302 & 90.685 & 91.194 & 91.871 & 92.929 & 94.560 \\
\hline 633.99 & 95 & 95.310 & 95.705 & 96.229 & 96.926 & 98.011 & 99.680 \\
\hline 760.00 & 100 & 100.319 & 100.726 & 101. 265 & 101.983 & 103.096 & 104.804 \\
\hline 906.06 & 105 & 105.329 & 105. 748 & 106. 303 & 107.042 & 108.183 & 109. 935 \\
\hline $1,074.58$ & 110 & 110.340 & 110.771 & 111.343 & 112.102 & 113.273 & 115.070 \\
\hline $1,268.03$ & 115 & 115.352 & 115. 793 & 116.385 & 117.163 & 118.365 & 120. 212 \\
\hline $1,489.14$ & 120 & 120.365 & 120.819 & 121.428 & 122. 225 & 123.460 & 125. 359 \\
\hline
\end{tabular}

were evaluated by the method of least squares. These constants are given in table 7 for several reference pressures over the range 200 to $1,500 \mathrm{~mm}$. As the deviations given in the last two columns are considerably larger than the experimental precision, these equations were not used to evaluate $\Delta t$. They

TABLE 5. Tapor-pressure-temperature relationships of dextrose solutions

\begin{tabular}{|c|c|c|c|c|c|}
\hline \multicolumn{6}{|c|}{$\log p=A-\frac{B}{C+t}$} \\
\hline $\begin{array}{l}\text { Concen- } \\
\text { tration of } \\
\text { dextrose }\end{array}$ & A & $B$ & C & $\begin{array}{l}\text { Average } \\
\text { devi- } \\
\text { ation }\end{array}$ & $\begin{array}{l}\text { Maxi- } \\
\text { mum } \\
\text { deviation }\end{array}$ \\
\hline Percent & & & & $m m \mathrm{Hg}$ & $m m \mathrm{Hg}$ \\
\hline 10 & 7. 912637 & 1636. 365 & 224.883 & & +0.08 \\
\hline 20 & 7. 9023 & 3.713 & 224.6 & & -.1 \\
\hline 30 & 7. 9004 & 1637.2 & 224.8 & \pm & +.2 \\
\hline 40 & 7. 888662 & 1636. 304 & 224. & \pm . & +.1 \\
\hline 50 & 7. 853013 & 1622.430 & 223. 205 & \pm & -.1 \\
\hline 60 & 7. 779591 & 1587.450 & 219.244 & \pm .04 & +.17 \\
\hline
\end{tabular}

TABLE 6. Values of pressure, temperature, and rates of change of pressure with temperature for dextrose solutions

\begin{tabular}{|c|c|c|c|c|c|c|c|c|c|c|c|c|}
\hline \multirow{3}{*}{ Pressure } & \multicolumn{12}{|c|}{ Concentration of dextrose solutions } \\
\hline & \multicolumn{2}{|c|}{10 Percent } & \multicolumn{2}{|c|}{20 Percent } & \multicolumn{2}{|c|}{30 Percent } & \multicolumn{2}{|c|}{40 Percent } & \multicolumn{2}{|c|}{50 Percent } & \multicolumn{2}{|c|}{60 Percent } \\
\hline & $\begin{array}{l}\text { Tempera- } \\
\text { ture }\end{array}$ & $d p / d t$ & $\begin{array}{l}\text { Tempera- } \\
\text { ture }\end{array}$ & $d p / d t$ & $\begin{array}{l}\text { Tempera- } \\
\text { ture }\end{array}$ & $d p / d t$ & $\begin{array}{c}\text { Tempera- } \\
\text { ture }\end{array}$ & $d p / d t$ & $\begin{array}{c}\text { Tempera- } \\
\text { ture }\end{array}$ & $d p / d t$ & $\begin{array}{c}\text { Tempera- } \\
\text { ture }\end{array}$ & $d p / d t$ \\
\hline $\begin{array}{c}m m \mathrm{Hg} \\
\text { a } 100- \\
200 \\
300 \\
400\end{array}$ & $\begin{array}{l}{ }^{\circ} \mathrm{C} \\
51.87 \\
66.72 \\
76.17 \\
83.25\end{array}$ & $\begin{array}{c}\mathrm{mm} /{ }^{\circ} \mathrm{C} \\
4.92 \\
8.86 \\
12.47 \\
15.87\end{array}$ & $\begin{array}{l}{ }^{\circ} \mathrm{C} \\
52.17 \\
67.05 \\
76.52 \\
83.62\end{array}$ & $\begin{array}{c}m m /{ }^{\circ} \mathrm{C} \\
4.91 \\
8.84 \\
12.45 \\
15.84\end{array}$ & $\begin{array}{l}{ }^{\circ} \mathrm{C} \\
52.58 \\
67.50 \\
76.99 \\
84.11\end{array}$ & $\begin{array}{c}m m /{ }^{\circ} \mathrm{C} \\
4.90 \\
8.82 \\
12.41 \\
15.79\end{array}$ & $\begin{array}{l}{ }^{\circ} \mathrm{C} \\
53.11 \\
68.08 \\
77.61 \\
84.76\end{array}$ & $\begin{array}{c}m m /{ }^{\circ} \mathrm{C} \\
4.88 \\
8.79 \\
12.36 \\
15.73\end{array}$ & $\begin{array}{l}{ }^{\circ} \mathrm{C} \\
53.99 \\
69.02 \\
78.59 \\
85.77\end{array}$ & $\begin{array}{c}\mathrm{mm} /{ }^{\circ} \mathrm{C} \\
4.86 \\
8.75 \\
12.31 \\
15.65\end{array}$ & $\begin{array}{l}{ }^{\circ} \mathrm{C} \\
55.42 \\
70.51 \\
80.14 \\
87.36\end{array}$ & $\begin{array}{c}\mathrm{mm} /{ }^{\circ} \mathrm{C} \\
4.85 \\
8.71 \\
12.24 \\
15.55\end{array}$ \\
\hline $\begin{array}{l}500 \ldots \\
600 \\
700 \\
760 \\
800\end{array}$ & $\begin{array}{r}88.98 \\
93.82 \\
98.03 \\
100.32 \\
101.77\end{array}$ & $\begin{array}{l}19.13 \\
22.26 \\
25.30 \\
27.08 \\
28.25\end{array}$ & $\begin{array}{r}89.36 \\
94.21 \\
98.43 \\
100.73 \\
102.18\end{array}$ & $\begin{array}{l}19.08 \\
22.20 \\
25.23 \\
27.01 \\
28.18\end{array}$ & $\begin{array}{r}89.87 \\
94.73 \\
98.96 \\
101.27 \\
102.72\end{array}$ & $\begin{array}{l}19.03 \\
22.14 \\
25.16 \\
26.93 \\
28.10\end{array}$ & $\begin{array}{r}90.54 \\
95.42 \\
99.67 \\
101.98 \\
103.44\end{array}$ & $\begin{array}{l}18.95 \\
22.05 \\
25.06 \\
26.82 \\
27.98\end{array}$ & $\begin{array}{r}91.58 \\
96.50 \\
100.77 \\
103.10 \\
104.56\end{array}$ & $\begin{array}{l}18.85 \\
21.93 \\
24.92 \\
26.67 \\
27.82\end{array}$ & $\begin{array}{r}93.21 \\
98.16 \\
102.46 \\
104.81 \\
106.29\end{array}$ & $\begin{array}{l}18.72 \\
21.77 \\
24.72 \\
26.46 \\
27.59\end{array}$ \\
\hline $\begin{array}{l}900 \ldots \\
1,000 \ldots \\
1,100 \ldots \\
1,200 \ldots\end{array}$ & $\begin{array}{l}105.14 \\
108.21 \\
111.04 \\
113.67\end{array}$ & $\begin{array}{l}31.14 \\
33.96 \\
36.73 \\
39.45\end{array}$ & $\begin{array}{l}105.55 \\
108.64 \\
112.47 \\
114.11\end{array}$ & $\begin{array}{l}31.06 \\
33.87 \\
36.63 \\
39.34\end{array}$ & $\begin{array}{l}106.11 \\
109.20 \\
112.05 \\
114.69\end{array}$ & $\begin{array}{l}30.97 \\
33.77 \\
36.53 \\
39.23\end{array}$ & $\begin{array}{l}106.85 \\
109.95 \\
112.81 \\
115.46\end{array}$ & $\begin{array}{l}30.84 \\
33.63 \\
36.37 \\
39.06\end{array}$ & $\begin{array}{l}107.99 \\
111.11 \\
113.99 \\
116.65\end{array}$ & $\begin{array}{l}30.65 \\
33.43 \\
36.14 \\
38.81\end{array}$ & $\begin{array}{l}109.74 \\
112.89 \\
115.79 \\
118.48\end{array}$ & $\begin{array}{l}30.40 \\
33.14 \\
35.82 \\
38.46\end{array}$ \\
\hline $\begin{array}{l}1,300 \\
1,400 \\
1,500 \\
{ }^{1} 1,600\end{array}$ & $\begin{array}{l}116.12 \\
118.42 \\
120.59 \\
122.65\end{array}$ & $\begin{array}{l}42.12 \\
44.76 \\
47.35 \\
49.91\end{array}$ & $\begin{array}{l}116.57 \\
118.87 \\
121.05 \\
123.11\end{array}$ & $\begin{array}{l}42.01 \\
44.64 \\
47.22 \\
49.78\end{array}$ & $\begin{array}{l}117.15 \\
119.47 \\
121.65 \\
123.72\end{array}$ & $\begin{array}{l}\text { 41. } 89 \\
44.50 \\
47.08 \\
49.63\end{array}$ & $\begin{array}{l}117.94 \\
120.26 \\
122.46 \\
124.54\end{array}$ & $\begin{array}{l}41.71 \\
44.31 \\
46.88 \\
49.41\end{array}$ & $\begin{array}{l}119.15 \\
121.49 \\
123.70 \\
125.79\end{array}$ & $\begin{array}{l}41.44 \\
44.02 \\
46.57 \\
49.08\end{array}$ & $\begin{array}{l}121.00 \\
123.36 \\
125.59 \\
127.70\end{array}$ & $\begin{array}{l}41.05 \\
43.60 \\
46.11 \\
48.59\end{array}$ \\
\hline
\end{tabular}

a Extrapolated values, 
TABLE 7. Boiling-point elevation of dextrose solutions

\begin{tabular}{|c|c|c|c|c|c|c|}
\hline \multicolumn{7}{|c|}{$\log \Delta t=\alpha+\beta C+\gamma C^{2}+\delta C^{3}$} \\
\hline Pressure & $\alpha$ & $\beta$ & $\gamma$ & $\delta$ & $\begin{array}{l}\text { Average } \\
\text { deviation }\end{array}$ & $\underset{\text { deviation }}{\operatorname{maximum}}$ \\
\hline $\begin{array}{r}m m \mathrm{Hg} \\
233.72 \\
355.22 \\
525.86 \\
760.00 \\
1,074.58 \\
1,489.14\end{array}$ & $\begin{array}{r}-0.989843 \\
-.982743 \\
-.967871 \\
-.944029 \\
-.918243 \\
-.885843\end{array}$ & $\begin{array}{l}\text { 5. } 113375 \times 10^{-2} \\
\text { 5. } 191070 \\
\text { 5. } 239106 \\
\text { 5. } 235447 \\
\text { 5. } 251193 \\
\text { 5. } 225459\end{array}$ & $\begin{array}{l}-7.377463 \times 10^{-4} \\
-7.435453 \\
-7.477459 \\
-7.427223 \\
-7.490898 \\
-7.476027\end{array}$ & $\begin{array}{l}\text { 5. } 526503 \times 10^{-6} \\
\text { 5. } 463234 \\
\text { 5. } 427242 \\
\text { 5. } 345987 \\
\text { 5. } 396036 \\
5.404016\end{array}$ & $\begin{array}{l}{ }^{\circ} \mathrm{C} \\
\pm 0.017 \\
\pm .023 \\
\pm .028 \\
\pm .031 \\
\pm .033 \\
\pm .033\end{array}$ & $\begin{array}{l}{ }^{\circ} \mathrm{C} \\
+0.032 \\
+.045 \\
+.055 \\
+.061 \\
+.067 \\
+.067\end{array}$ \\
\hline
\end{tabular}

are useful, however, in calculating the boiling point elevations of dextrose solutions to within $0.05^{\circ}$ to $0.1^{\circ} \mathrm{C}$.

Molal boiling point elevations of aqueous solutions of dextrose have been measured by Juettner [8], but only at normal atmospheric pressure. A com-

TABLE 8. Molal boiling-point elevation of dextrose solutions $(760 \mathrm{~mm} \mathrm{Hg})$

\begin{tabular}{|c|c|c|}
\hline Molality & Juettner [8] & This paper \\
\hline $\begin{array}{l}1 \\
2 \\
3\end{array}$ & $\begin{array}{c}{ }^{\circ} \mathrm{C} / \text { mole } \\
0.53 \\
.53 \\
.53\end{array}$ & $\begin{array}{c}{ }^{\circ} \mathrm{C} / \mathrm{mole} \\
0.520 \\
.525 \\
.531\end{array}$ \\
\hline $\begin{array}{l}4 \\
5 \\
6\end{array}$ & & $\begin{array}{l}.537 \\
.544 \\
.552\end{array}$ \\
\hline $\begin{array}{l}7 \\
8 \\
9\end{array}$ & - & $\begin{array}{l}.561 \\
.570 \\
.580\end{array}$ \\
\hline
\end{tabular}

parison of his values with those of this investigation is given in table 8. Apparently, there are no other published measurements of the vapor pressures of aqueous solutions of dextrose in the range reported in this paper.

\section{References}

[1] N. S. Osborne, H. F. Stimson, and D. C. Ginnings, J. Research NBS 23, 261 (1939) RP1229.

[2] E. R. Smith, J. Research NBS 24, 229 (1940) RP1280.

[3] G. W. Thomson, Chem. Rev. 38, 1 (1946).

[4] F. J. Bates and Associates, Polarimetry, saccharimetry, and the sugars, NBS Circular C440, p. 365 (1942).

[5] W. Swietoslawski, Ebulliometry (Reinhold Publishing Corp., New York, N.Y., 1945).

[6] H. S. Isbell and W. W. Pigman, J. Research NBS 18, 178 (1937) RP969.

[7] E. R. Smith and H. Matheson, J. Research NBS 20, 641 (1938) RP1097.

[8] F. Juettner, Z. physik. Chem. 38, 76 (1901); Int. Crit. Tables III, 327 (1928).

Washington, July 17, 1950 。

\title{
Wavelengths for Calibration of Prism Spectrometers
}

\section{By Earle K. Plyer and C. Wilbur Peters ${ }^{1}$}

\begin{abstract}
Several absorption bands of polystyrene, 1,2,4-trichiorobenzene, and other compounds have been measured in the infrared region from 1.5 to $24 \mu$ on grating spectrometers. These bands have been determined with sufficient accuracy for use in calibration of prism instruments. A table is included that gives the cell thicknesses used in the measurements. The emission lines of mercury for the region from 0.5 to $2.4 \mu$ are included. In order that the table may be of most value, a number of bands that have been determined by previous observers have also been included.
\end{abstract}

Many infrared absorption bands have been carefully measured, and their reported wavelengths $[1]^{2}$ are useful for calibrating spectrometers. Techniques of calibration utilizing vibrational bands with resolved rotational structures, including those of ammonia, carbon dioxide, and water vapor, have been described by Oetjen, Kao, and Randall [2]. When one undertakes to calibrate an infrared spectrometer he soon finds that additional reference lines or bands would be extremely helpful and that the information available has some serious disadvantages. In certain regions there are an insufficient number of

\footnotetext{
1 University of Michigan.

Figures in brackets indicate the literature references at the end of this paper.
}

standards. In some cases where a band has a rotational fine structure that is not resolved by a prism, it is not possible to locate any individual band with sufficient precision to justify its use for calibration. Furthermore, some absorbing materials require impractically long absorption cells. To avoid these disadvantages and increase the number of calibration points, additional lines and bands in the region from the visible to $24 \mu$ have been measured by using sources or absorbers convenient for the calibration of prism instruments. These include: (1) polystyrene films and trichlorobenzene, which prove standards between 15 and $24 \mu$; (2) $\mathrm{AH}-4$ mercury lamp in the region visible to $24 \mu$; (3) toluene at $21.5 \mu$; 